\title{
Salicylic acid and jasmonic acid alter physiological performance, assimilate mobilization and seed filling of soybean under salt stress
}

\author{
Kazem GHASSEMI-GOLEZANI $^{1 *}$, Salar FARHANGI-ABRIZ ${ }^{1}$, Ali BANDEHAGH ${ }^{2}$
}

Received April 30, 2018; accepted October 22, 2018.

Delo je prispelo 30. aprila 2018, sprejeto 22. oktobra 2018.

\begin{abstract}
This research was conducted to investigate the morphophysiological effects of salicylic acid and jasmonic acid on soybean performance and productivity under salinity. Leaf chlorophyll content index, carotenoids and anthocyanins content, photosystem II efficiency, relative water content, leaf area, leaf mass, specific leaf area, water use efficiency, seed filling duration, assimilate mobilization efficiency and seed mass decreased, but leaf temperature, specific leaf mass and electrolytic leakage of leaves increased with enhancing salinity. Salicylic acid improved leaf chlorophyll content index, anthocyanins content, leaf area, specific leaf area, water use efficiency, seed filing duration, assimilate mobilization efficiency and seed mass under both saline and non-saline conditions. The superior effects of salicylic acid on some traits such as maximum quantum yield of PSII, relative water content and leaf electrolytic leakage only occurred under different salinity levels. Jasmonic acid improved leaf mass, specific leaf mass, carotenoids content, relative water content, seed filling rate and reduced chlorophyll content index, leaf temperature, leaf area, specific leaf area, seed filling duration, assimilates mobilization efficiency and relative electrolytic leakage of soybean, with no significant effects on photosystem II efficiency and seed mass. Application of salicylic acid was, therefore, the superior treatment for enhancing physiological performance and seed mass of soybean plants under different salinity levels.
\end{abstract}

Key words: chlorophyll content; jasmonic acid; salicylic acid; salinity; seed production; soybean

\section{IZVLEČEK}

\author{
SALICILNA IN JASMONSKA KISLINA \\ SPREMINJATA FIZIOLOŠKE PROCESE, \\ MOBILIZACIJO ASIMILATOV IN POLNJENJE \\ SEMEN SOJE V RAZMERAH SOLNEGA STRESA
}

Raziskava je bila izvedena za preučitev morfo-fizioloških učinkov salicilne in jasmonske kisline na rast in produktivnost soje v razmerah slanosti. Parametri kot so indeks vsebnosti klorofila listov, vsebnost karotenoidov in antocianinov, učinkovitost fotosistema II, relativna vsebnost vode, listna površina, listna masa, specifična listna površina, učinkovitost izrabe vode, trajanje polnjenja semen, učinkovitost mobilizacije asimilatov in masa semen so se zmanjšali medtem, ko so se parametri kot so temperatura listov, specifična listna masa in puščanje elktrolitov povečali $\mathrm{Z}$ naraščajočo slanostjo. Salicilna kislina je izboljšala indeks vsebnosti klorofila listov, povečala vsebnost antocianinov, listno površino, specifično listno površino, učinkovitost izrabe vode, trajanje polnjenja semen, učinkovitost mobilizacije asimilatov in maso semen $\mathrm{v}$ razmerah slanosti in brez nje. Večji učinki salicilne kisline na nekatere preučevane parametre kot so maksimalna učinkovitost PSII, relativna vsebnost vode in puščanje elektrolitov iz listov so se pojavili samo $\mathrm{v}$ nekaterih ravneh slanosti. Jasmonska kislina je povečala maso listov, specifično listno maso, vsebnost karotenoidov, relativno vsebnost vode, hitrost polnjenja semena in zmanjšala indeks vsebnosti klorofilov, temperaturo listov, listno površino, specifično listno površino, trajanje polnjenja semena, učinkovitost mobilizacije asimilatov in relativno puščanje elktrolitov brez značilnih učinkov na učinkovitost PSII in maso semen. Uporaba salicilne kisline je bilo primernejše obravnavanje za povečanje fiziološke aktivnosti in mase semen soje v različnih razmerah slanosti.

Ključne besede: vsebnost klorofila; jasmonska kislina; salicilna kislina; slanost; tvorba semena; soja

\footnotetext{
1 Department of Plant Eco-physiology, Faculty of Agriculture, University of Tabriz, Tabriz, Iran; *Corresponding author: golezani@ gmail.com

2 Department of Plant Breading and Biotechnology, Faculty of Agriculture, University of Tabriz, Tabriz, Iran
} 


\section{INTRODUCTION}

Soybean originates from China and is a major source of protein and oil for humans and as a high-quality animal feed. Soybean is a crop sensitive-to-moderately tolerant to salinity (Luo et al., 2005). Salinity enhances ion toxicity and reduces photosynthesis. The reduction in photosynthesis under salinity could be attributed to a decrease in chlorophyll and other photosynthetic pigments contents (Sali et al., 2015). Salinity can affect the chlorophyll content through inhibition of chlorophyll synthesis or an acceleration of its degradation (Reddy \& Vora, 1986). The maximum quantum yield of PSII (Fv/Fm) could also be reduced by salt stress. Disturbances of photosynthesis at the molecular level are related to the restricted electron transport through PSII and/or with structural injuries to PSII (Ghassemi-Golezani \& Lotfi, 2015). Under environmental stresses such as drought and salinity, plant leaves are dehydrated, and photosynthesis is decreased. The decrease in photosynthesis of dehydrated leaves usually results from a decrease in stomatal conductance and transpiration (Mirfattahi et al., 2017). As a consequence of the reduction in transpiration rate, leaf temperature increases (Mohammadian et al., 2015). Salinity can also reduce seed yield by decreasing physiological performance and accelerating seed filling period (Ghassemi-Golezani et al., 2010).

Growth inhibition, poor performance and decreasing seed yield of plants under salinity are attributed to osmotic stress imposed by salinity and to specific ion $\left(\mathrm{Na}^{+}\right)$toxicity (Farhangi-Abriz \& Ghassemi-Golezani, 2018). In soybean, the number of seeds, pods and yield are directly related to the number of flowers per nodes and node number can be reduced by environmental stresses (Jiang \& Egli, 1993). Moreover, several reports have shown that salinity increases the reactive oxygen species (ROS) and decreases seed filling duration (Ghassemi-Golezani et al., 2010; Farhangi-Abriz \& Ghassemi-Golezani, 2018). In soybean seeds, the dynamic seed filling period begins when the pod wall has approximately reached its final size. At the end of this phase, cell division stops, linear dry matter accumulation begins in cotyledons and continues until mass maturity. Mass maturity (end of seed filling phase) in soybean cultivars can be classified according to the duration of the life cycle, being early, semi-early, medium, late medium and late, according to Oya et al. (2004) and Ghassemi-Golezani et al. (2010). GhassemiGolezani et al. (2010) showed that salinity reduced seed filling period and yield in different cultivars of soybean.

Application of some growth regulators or plant hormones has been expanded to improve plant growth and development under stress and non-stress conditions. Salicylic acid (SA) is a plant phenolic compound and now considered as a hormone-like endogenous regulator. It plays diverse physiological roles in plants, which include plant growth, flower induction, nutrient uptake, stomatal movements, photosynthesis and enzyme activities (Hayat et al., 2007). Former reports show that SA plays important regulatory roles in plants against a wide range of environmental stresses (Choudhury \& Panda, 2004; Gunes et al., 2007). Application of SA improves physiological performance of the crops (Shi et al., 2006; Farhangi-Abriz \& Ghassemi-Golezani et al., 2018). Ghassemi-Golezani \& Farhangi-Abriz (2018a) also reported that foliar application of SA stimulates the $\mathrm{H}^{+}$-ATPase activity of tonoplast, nutrient uptake and salt tolerance of soybean.

Jasmonates are ubiquitously-occurring lipid-derived compounds with signal function in plant responses to abiotic and biotic stresses, as well as in plant growth and development (Wasternack, 2007). Foliar application of jasmonic acid (JA) modulates several physiological responses, improving resistance against abiotic stresses (Farhangi-Abriz \& Ghassemi-Golezani, 2018). JA application to the stressed plants reduces the amount of lipid peroxidation and stimulates the synthesis of antioxidant enzymes, enhancing the physiological performance and seed yield of Artemisia (Aftab et al., 2011). Previous studies have helped to understand the effects of SA and JA on decreasing destructive effects of salt toxicity in plants (Farhangi-Abriz \& GhassemiGolezani, 2018), however the possible effects of SA and JA on the productivity of soybean under salt stress were not documented so far. Thus, this research was conducted to investigate: 1) the effects of SA and JA on some morpho-physiological traits of soybean under salt toxicity and 2) the effects of these growth regulators on soybean grain filling and productivity under saline and non-saline conditions.

\section{MATERIALS AND METHODS}

\subsection{Experimental conditions}

This experiment was carried out in 2016 with a factorial arrangement on the basis of randomized complete block design with four replications at the greenhouse of the University of Tabriz, Iran. In each plastic pot, containing $1 \mathrm{~kg}$ perlite, seeds of soybean (M7 cultivar) 
were sown and then tap water (non-saline) and saline

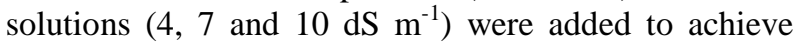
$100 \%$ FC (Field capacity). All pots were placed in a glass greenhouse with a day-night mean temperatures of $28-26^{\circ} \mathrm{C}$ and $35-40$ relative humidity, natural light intensify and photoperiod. During the growth period, the pots were weighed and the losses were made up with the Hoagland solution (electrical conductivity $=1.3 \mathrm{dS}$ $\mathrm{m}^{-1}$, $\mathrm{pH}$ 6.7-7.2). For avoiding extra electrical conductivity (EC), due to adding the Hoagland solution, perlites within the pots were washed every 30 days and non-saline and salinity treatments were reapplied. Salicylic acid $(1 \mathrm{mM})$ and jasmonic acid $(0.5 \mathrm{mM})$ were separately sprayed on plants at vegetative (V3) and flowering stages (R2).

\subsection{Chlorophyll content index (CCI)}

Leaf CCI was measured using a portable chlorophyll meter (CCM-200, Opti-Sciences, USA). Two plants were selected in each pot and the CCI of the upper, middle and lower leaves of each plant was measured at the beginning of pod development (R3). Subsequently, the mean CCI for each treatment at each replicate was determined.

\subsection{Anthocyanins and carotenoids contents}

About $0.2 \mathrm{~g}$ of leaf samples were homogenized in $4 \mathrm{ml}$ acetone $(80 \%)$, and then centrifuged at $12,000 \mathrm{~g}$ for 20 $\min$ at $4{ }^{\circ} \mathrm{C}$. The supernatant was collected and absorbance was recorded at $480 \mathrm{~nm}$ and $510 \mathrm{~nm}$, using a spectrophotometer (Model Analytikjena Spekol 1500 Germany) (Maclachlan \& Zalik, 1963). Another $0.2 \mathrm{~g}$ of leaf sample was homogenized in $3 \mathrm{ml}$ extraction mixture $(0.6 \mathrm{ml}$ water, $2.37 \mathrm{ml}$ methanol and $0.03 \mathrm{ml}$ $\mathrm{HCl}$ ) followed by centrifugation at $12,000 \mathrm{~g}$ for $20 \mathrm{~min}$ at $4{ }^{\circ} \mathrm{C}$. The absorbance of supernatant was read at 530 $\mathrm{nm}$ and $657 \mathrm{~nm}$ (Mancinelli, 1984).

\subsection{Maximum quantum yield of PSII (Fv/Fm)}

At early pod filling stage, maximum quantum yield of PSII $\left(\mathrm{F}_{\mathrm{v}} / \mathrm{F}_{\mathrm{m}}\right)$ was measured using a portable chlorophyll fluorometer (OS-30, Opti-Sciences, USA). Darkadapted leaves $(30 \mathrm{~min})$ were initially exposed to the weak modulate measuring beam, followed by exposure to saturated white light to estimate the initial $\left(\mathrm{F}_{0}\right)$ and maximum $\left(\mathrm{F}_{\mathrm{m}}\right)$ fluorescence values, respectively. Variable fluorescence $\left(\mathrm{F}_{\mathrm{v}}\right)$ was calculated by subtracting $\mathrm{F}_{0}$ from $\mathrm{F}_{\mathrm{m}}$.

\subsection{Leaf temperature (LT)}

Two plants were selected in each pot and LT $\left({ }^{\circ} \mathrm{C}\right)$ of upper, middle and lower leaves were measured by an infrared thermometer (TES-1327) at beginning pod development stage. Then the mean temperature for each treatment was determined.

\subsection{Leaf area (LA) and dry mass (LDM)}

LA per plant was measured at the beginning pod formation stage using a leaf area meter (ADC-AM 300). Leaves per plant were dried in an oven at $80{ }^{\circ} \mathrm{C}$ for $48 \mathrm{~h}$ and then weighed. After determining leaf area and leaf mass, specific leaf area (SLA) and specific leaf mass (SLM) were calculated as:

$\mathrm{SLA}=\mathrm{LA}\left(\mathrm{mm}^{2}\right) / \mathrm{LDM}(\mathrm{mg})$

$\mathrm{SLM}=\mathrm{LDM}(\mathrm{mg}) / \mathrm{LA}\left(\mathrm{mm}^{2}\right)$

\subsection{Relative electrolytic leakage (REL)}

About $1 \mathrm{~g}$ of leaf sample was washed with deionized water and then placed in tubes with $15 \mathrm{ml}$ of deionized water and incubated for 2 hours at $25^{\circ} \mathrm{C}$. Subsequently, the electrical conductivity of the solution $\left(\mathrm{L}_{1}\right)$ was determined. Samples were then autoclaved at $100{ }^{\circ} \mathrm{C}$ for 30 minutes, and the conductivity $\left(\mathrm{L}_{2}\right)$ was recorded after cooling to $25^{\circ} \mathrm{C}$. Then, the EL was calculated as (Lutts et al., 1996).

$\operatorname{REL}(\%)=\left(\frac{L 1}{L 2}\right) \times 100$

\subsection{Relative water content (RWC)}

Relative water content of soybean leaves was determined according to Barrs and Weatherley. (1962) method. At the beginning of pod development, fresh mass $\left(F_{M}\right)$ of the youngest fully expanded leaf was recorded. Turgid mass $\left(\mathrm{T}_{\mathrm{M}}\right)$ was obtained after waterlogged the leaf for $24 \mathrm{~h}$ in distilled water. Finally, leaf dry mass $\left(\mathrm{D}_{\mathrm{M}}\right)$ was determined after drying at the $80{ }^{\circ} \mathrm{C}$ for $24 \mathrm{~h}$. The value of RWC was calculated using the following equation:

$\mathrm{RWC}=\left[\left(\mathrm{F}_{\mathrm{M}}-\mathrm{D}_{\mathrm{M}}\right) /\left(\mathrm{T}_{\mathrm{M}}-\mathrm{D}_{\mathrm{M}}\right)\right] \times 100$

\subsection{Water use efficiency (WUE)}

Increasing seed mass per plant during seed development was estimated as the difference between the seed mass at the beginning and the end of the seed filling period. Crop water used up over these periods was estimated from the sum of the per diem water intake to the pots. WUE was determined as:

WUE $\left(\mathrm{g} \mathrm{l}^{-1}\right)=($ seed mass at final stage - seed mass at first stage)/total water used up

\subsection{Rate and duration of seed filling}

During seed filling from seed formation (R5) up to full maturity (R8), two plants were harvested from each pot in 10 days' intervals at five stages. Seeds of each sample were oven-dried at $80{ }^{\circ} \mathrm{C}$ for $48 \mathrm{~h}$ and then seed dry mass was determined. Maximum seed mass and 
seed filling duration were estimated, using a two-piece regression model by SAS 9.1.3 software:

$$
M= \begin{cases}a+b t & t<t m \\ a+b t & t \geq t m\end{cases}
$$

Where M is seed mass, $a$ is the intercept, $\boldsymbol{b}$ is the slope, $\boldsymbol{t}$ is days after flowering and tm is the end of seed filling period (time of mass maturity). Subsequently, seed filling rate (SFR) was calculated as:

$\mathrm{SFR}=\mathrm{MSM} / \mathrm{SFD}$

Where MSM is maximum seed mass and SFD is seed filling duration.

\subsection{Assimilate mobilization efficiency}

Assimilate mobilization efficiency in the seeds was calculated, using seed mass at the first and final stages of seed filling:
$\mathrm{AME}=\left(\mathrm{SM}_{\mathrm{F}-} \mathrm{SM}_{\mathrm{P}}\right) / \mathrm{SW}_{\mathrm{F}} \times 100$

Where AME is the assimilate mobilization efficiency during seed filling, $\mathrm{SM}_{\mathrm{F}}$ is the amount of seeds mass at the final stage $(\mathrm{mg})$ and $\mathrm{SM}_{\mathrm{P}}$ is the amount of assimilates at the primary stage $(\mathrm{mg})$.

\subsection{Yield components}

At maturity (R8), two plants from each pot were harvested and pods and seeds per plant were determined.

\subsection{Analysis of Variance}

After testing the normality and homogeneity of variance by Shapiro-Wilk test, the data were analyzed and the means were compared at $\mathrm{p} \leq 0.05$ by Duncan multiple range test, using MSTATC software. The figures were drawn by Excel software.

\section{RESULTS}

\subsection{Chlorophyll content index (CCI)}

Analysis of variance showed significant effects of salinity and hormonal application on soybean CCI. The CCI was decreased with increasing salinity. Plants with SA treatment showed the highest level of the CCI, but JA reduced the CCI (Table 1).

\subsection{Carotenoids and anthocyanins}

The carotenoids and anthocyanins in soybean leaves were significantly affected by salinity and hormonal treatments. Salinity reduced leaf carotenoids and anthocyanins, but treatment with JA increased these pigments. Treatment with SA only improved anthocyanins with no tangible effect on carotenoids (Table 1).

\subsection{Leaf temperature}

The effects of salinity and hormonal sprays on leaf temperature were significant. The leaf temperature increased as a consequence of enhancing salinity. Foliar application of SA and JA significantly reduced the leaf temperature (Table 1).

Table 1: : Means of morpho-physiological traits of soybean leaf under different levels of salinity and hormonal treatments

\begin{tabular}{|c|c|c|c|c|c|c|c|c|}
\hline Treatments & $\begin{array}{l}\text { Chlorophyll } \\
\text { content } \\
\text { index }\end{array}$ & $\begin{array}{l}\text { Carotenoid } \\
\quad\left(\mathrm{mg} \mathrm{g}^{-}\right. \\
\left.{ }^{1} \mathrm{DM}\right)\end{array}$ & $\begin{array}{l}\text { Anthocyanin } \\
\left(\mathrm{mg} \mathrm{g}^{-1} \mathrm{DM}\right)\end{array}$ & $\begin{array}{c}\text { Leaf } \\
\text { temperature } \\
\left({ }^{\circ} \mathrm{C}\right)\end{array}$ & $\begin{array}{l}\text { Leaf } \\
\text { area } \\
\left(\mathrm{mm}^{2}\right)\end{array}$ & $\begin{array}{l}\text { Leaf } \\
\text { dry mass } \\
\text { (mg) }\end{array}$ & $\begin{array}{c}\text { Specific } \\
\text { leaf area } \\
\left(\mathrm{mm}^{2} \mathrm{mg}^{-}\right.\end{array}$ & $\begin{array}{l}\text { Specific } \\
\text { leaf mass } \\
\left(\mathrm{mg} \mathrm{mm}_{2}^{-}\right.\end{array}$ \\
\hline Salinity & & & & & & & & \\
\hline $0 \mathrm{dS} \mathrm{m}^{-1}$ & $20.63 a$ & $0.71 \mathrm{a}$ & $0.28 \mathrm{a}$ & $20.26 \mathrm{~d}$ & 26790a & $2110 a$ & $12.68 \mathrm{a}$ & $0.078 b$ \\
\hline $4 \mathrm{dS} \mathrm{m}^{-1}$ & $19.40 \mathrm{~b}$ & $0.67 b$ & $0.24 b$ & $20.99 c$ & $26860 \mathrm{a}$ & $2120 \mathrm{a}$ & $12.64 \mathrm{a}$ & $0.079 b$ \\
\hline $7 \mathrm{dS} \mathrm{m}^{-1}$ & $18.24 \mathrm{c}$ & $0.55 \mathrm{c}$ & $0.20 \mathrm{c}$ & $23.15 b$ & 21570b & $1910 \mathrm{~b}$ & $11.27 \mathrm{~b}$ & $0.090 \mathrm{a}$ \\
\hline $10 \mathrm{dS} \mathrm{m}^{-1}$ & $17.12 d$ & $0.45 \mathrm{~d}$ & $0.17 \mathrm{~d}$ & $24.25 \mathrm{a}$ & $18610 \mathrm{c}$ & $1700 \mathrm{c}$ & $10.95 c$ & $0.091 \mathrm{a}$ \\
\hline \multicolumn{9}{|l|}{$\begin{array}{l}\text { Hormonal } \\
\text { treatments }\end{array}$} \\
\hline Con & $18.83 b$ & $0.56 \mathrm{~b}$ & $0.19 \mathrm{c}$ & $22.54 \mathrm{a}$ & $23430 \mathrm{~b}$ & $1940 \mathrm{~b}$ & $11.88 b$ & $0.084 b$ \\
\hline SA & $20.06 \mathrm{a}$ & $0.58 b$ & $0.22 b$ & $21.85 b$ & $24680 a$ & $1980 \mathrm{~b}$ & $12.45 \mathrm{a}$ & $0.081 b$ \\
\hline JA & $17.65 \mathrm{c}$ & $0.63 \mathrm{a}$ & $0.26 \mathrm{a}$ & $22.10 \mathrm{~b}$ & $22260 \mathrm{c}$ & $2140 \mathrm{a}$ & $10.41 \mathrm{c}$ & $0.097 \mathrm{a}$ \\
\hline
\end{tabular}

Con: Control, SA: Salicylic acid, JA: Jasmonic acid

Different letters in each column indicate significant difference at $\mathrm{p} \leq 0.05$ 


\subsection{Leaf area and mass}

Leaf area, leaf dry mass, specific leaf area and specific leaf mass were significantly affected by salinity and hormonal treatments. Leaf area and dry mass were reduced with enhancing salinity but the difference between non-saline and low salinity conditions were not significant. Foliar application of SA improved the leaf area with no significant effect on leaf mass, but JA showed vice-versa effect, despite reducing leaf area, increased leaf dry mass. Specific leaf area was reduced, but specific leaf mass was elevated under moderate and severe salinity levels. Application of SA increased specific leaf area, but had no significant effect on specific leaf mass. Treatment of plants with JA reduced the specific leaf area and increased specific leaf mass in comparison with control plants (Table 1).

\subsection{Maximum quantum yield of PSII ( Fv/Fm)}

Interaction of salinity $\times$ hormone for maximum quantum yield of PSII was significant. Fv/Fm was not changed significantly at $4 \mathrm{dS} \mathrm{m}^{-1}$ salinity, but thereafter it was diminished with enhanced salinity. The Fv/Fm for JA and SA treated plants were statistically similar up to $7 \mathrm{dS} \mathrm{m}^{-1}$, but SA treated plants in comparison with control and JA treatments showed the highest maximum quantum yield of PSII under severe salt stress (Fig. 1).
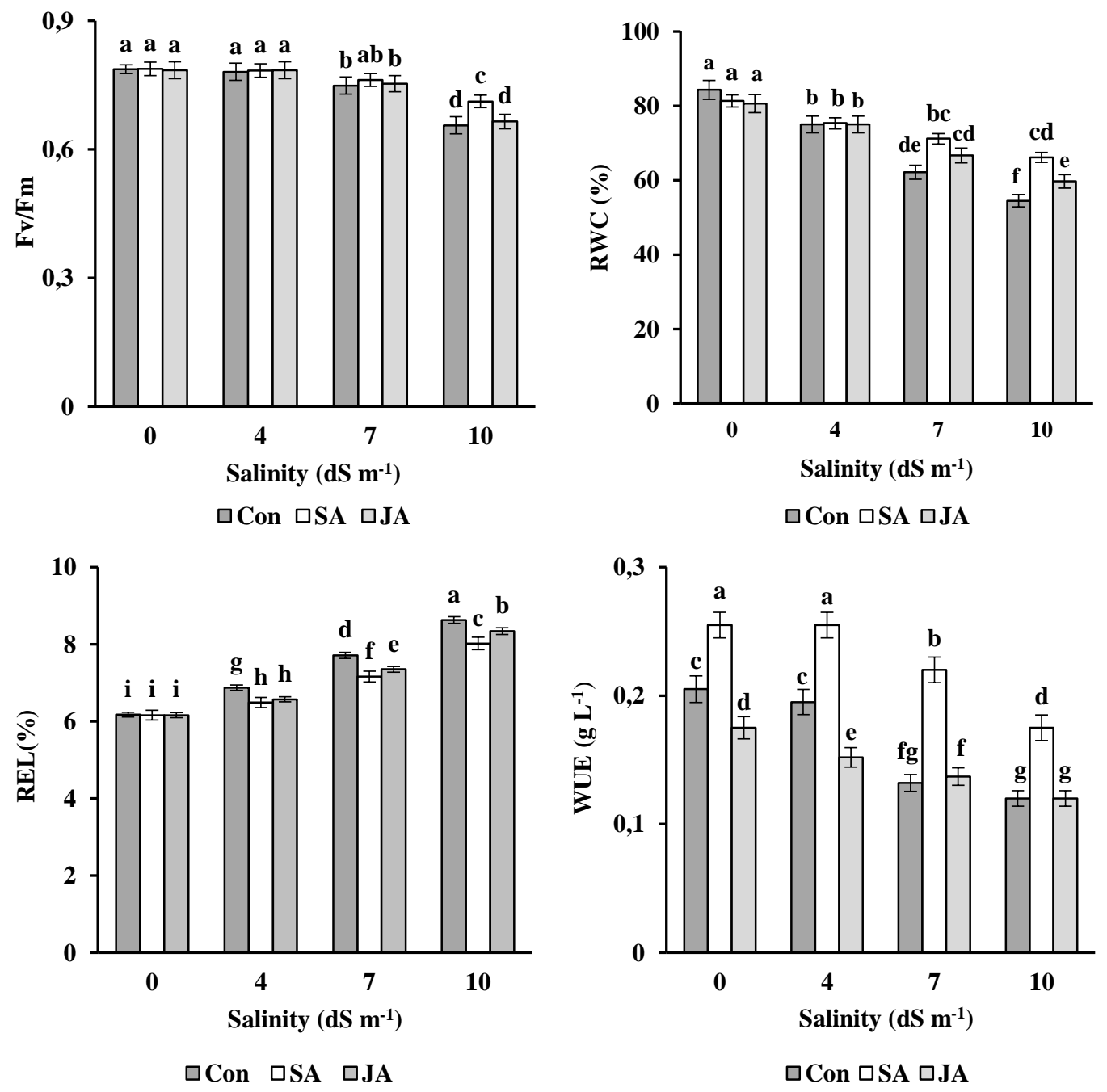

Figure 1: Changes in maximum quantum yield of PSII (Fv/Fm), relative electrolytic leakage (REL), water use efficiency (WUE) and relative water content (RWC) of soybean leaves under different levels of salinity and hormonal treatments. Different letters indicate significant difference at $\mathrm{p} \leq 0.05$. Con: control, SA: salicylic acid and JA: Jasmonic acid 


\subsection{Leaf electrolytic leakage}

Relative electrolytic leakage of soybean leaves was significantly enhanced by rising salt stress. Treatment of plants with SA and JA reduced the relative electrolytic leakage of soybean leaves under different levels of salt stress, but these hormonal treatments did not change this trait under non-saline condition (Fig. 1).

\subsection{Relative water content (RWC)}

The interaction of salinity $\times$ hormone for relative water content of soybean leaves was significant. Leaf relative water content was decreased as salt stress increased. Exogenous application of JA and SA under non-saline and low salinity conditions had no significant effect on RWC, but these treatments improved relative water content of soybean leaves under moderate and severe salinities (Fig. 1).

\subsection{Rate and duration of seed filling}

Seed mass was increased by increasing seed filling up to 39-56 days after flowering, depending on salinity level and hormonal treatments. Salinity reduced seed filling duration and increased seed filling rate. Maximum seed mass under salinity treatments was achieved about 6-12 days earlier than that under non-saline condition, and reduced with enhancing salinity levels. Treatment with SA under all salinity levels with rising seed filling duration increased maximum seed mass. Under non and low salinity levels, treatment with JA reduced seed filling duration, but in moderate and severe salinity levels, this reduction was not significant. JA increased seed filling rate of plants under all salinity levels, with no significant effect on control plants. Seeds from JA treated plants did not show significant difference with control plants in maximum seed mass (Fig. 2 and Tables 2 and 3$)$.

Table 2: Means of soybean seed filling duration, rate and assimilate mobilization efficiency under different salinity and hormonal treatments

\begin{tabular}{clccc}
\hline $\begin{array}{c}\text { Salinity } \\
\left(\mathrm{dS} \mathrm{m}^{-1}\right)\end{array}$ & $\begin{array}{c}\text { Hormonal } \\
\text { treatments }\end{array}$ & $\begin{array}{c}\text { Seed filling duration } \\
(\text { day })\end{array}$ & $\begin{array}{c}\text { Seed filling rate } \\
\left(\text { mg day }^{-1}\right)\end{array}$ & $\begin{array}{c}\text { Assimilate mobilization } \\
\text { efficiency }(\%)\end{array}$ \\
\hline \multirow{3}{*}{0} & Con & $44.75 \mathrm{~b}$ & $2.28 \mathrm{ef}$ & $66.24 \mathrm{~d}$ \\
& SA & $47.02 \mathrm{a}$ & $2.28 \mathrm{ef}$ & $68.78 \mathrm{bc}$ \\
& JA & $42.02 \mathrm{~d}$ & $2.34 \mathrm{e}$ & $61.46 \mathrm{f}$ \\
\hline \multirow{2}{*}{4} & Con & $42.91 \mathrm{c}$ & $2.46 \mathrm{~cd}$ & $70.03 \mathrm{~b}$ \\
& SA & $47.72 \mathrm{a}$ & $2.21 \mathrm{f}$ & $74.31 \mathrm{a}$ \\
& JA & $39.05 \mathrm{f}$ & $2.57 \mathrm{ab}$ & $64.08 \mathrm{e}$ \\
\hline \multirow{2}{*}{7} & Con & $37.24 \mathrm{~g}$ & $2.44 \mathrm{~cd}$ & $63.77 \mathrm{e}$ \\
& SA & $42.02 \mathrm{~d}$ & $2.38 \mathrm{de}$ & $65.70 \mathrm{~d}$ \\
& JA & $36.86 \mathrm{~g}$ & $2.61 \mathrm{ab}$ & $64.01 \mathrm{e}$ \\
\hline \multirow{2}{*}{10} & Con & $34.35 \mathrm{~h}$ & $2.51 \mathrm{bc}$ & $58.09 \mathrm{~g}$ \\
& SA & $41.23 \mathrm{e}$ & $2.28 \mathrm{ef}$ & $68.07 \mathrm{c}$ \\
& JA & $33.61 \mathrm{~h}$ & $2.63 \mathrm{a}$ & $58.65 \mathrm{~g}$ \\
\hline
\end{tabular}

Different letters in each column indicate significant difference at $\mathrm{p} \leq 0.05$. Con: control, SA: salicylic acid and JA: Jasmonic acid

Salinity and hormonal treatments significantly affected assimilates mobilization efficiency to the seeds during the seed filling period. Assimilates mobilization efficiency to the seeds was increased by enhancing salinity up to $4 \mathrm{dS} \mathrm{m}^{-1}$, but with further increase in salinity it was reduced. Under all levels of salinity and non-salinity, SA treatment significantly improved the mobilization efficiency; this advantageous effect was higher under severe salinity. The JA treatments under non and low salinity levels reduced the mobilization efficiency of assimilates to the seeds, however, under moderate and severe salinities, there was no tangible difference between the JA and control plants (Table 2). 

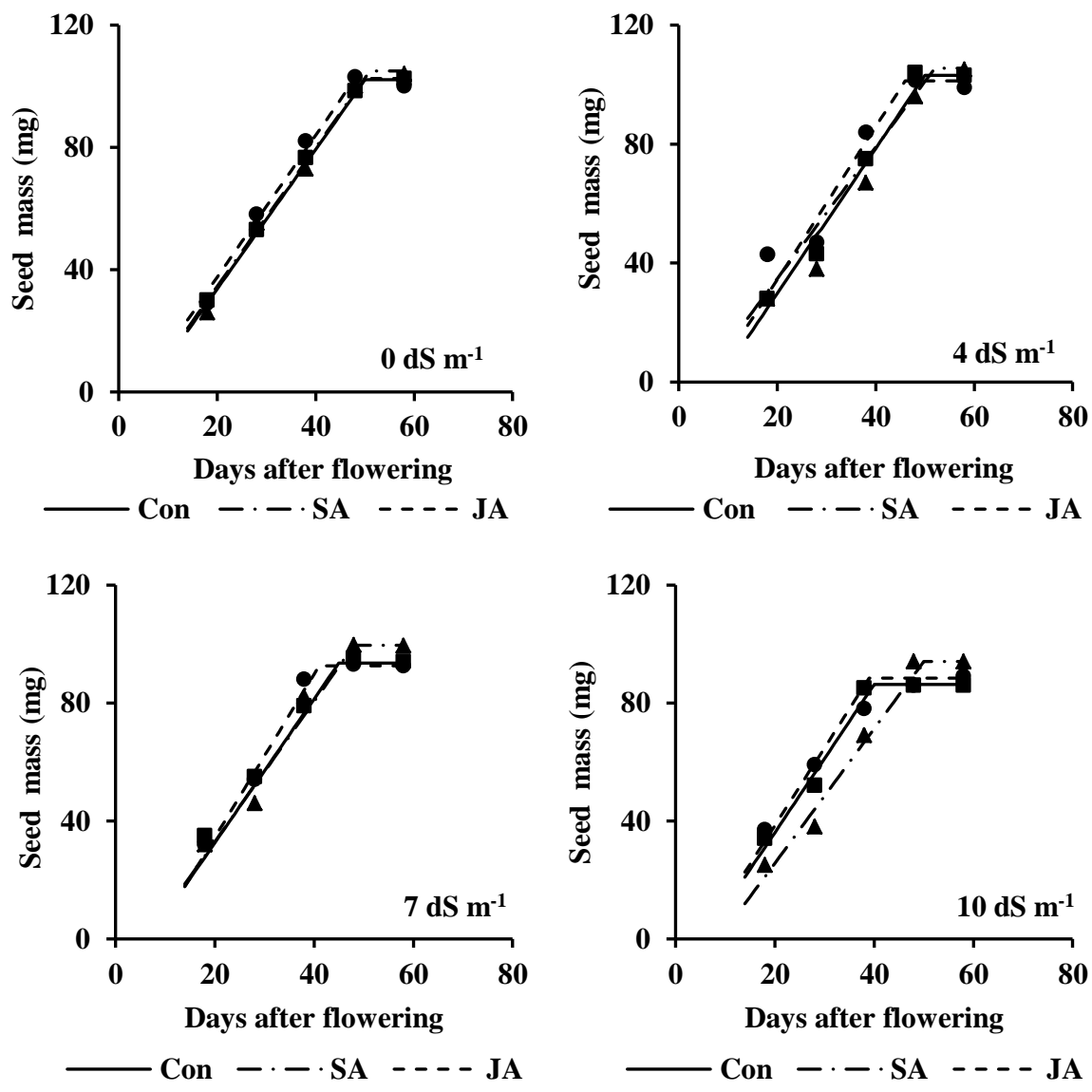

Figure 2: Changes in seed mass of soybean (M7 cultivar) in response to different salinity and hormonal treatments. Con: control, SA: salicylic acid and JA: Jasmonic acid

\subsection{Yield components}

The effects of salinity and hormonal treatments on pod and seed number per plant were significant. Pod and seed number per plant were decreased with rising salinity, however the difference in pod number between
$0 \mathrm{dS} \mathrm{m} \mathrm{m}^{-1}$ and $4 \mathrm{dS} \mathrm{m}^{-1}$ was not significant. Treatment with SA increased pod and seed number per plant, but JA did not improve number of the pods per plant (Table $3)$.

Table 3: Means of soybean seed mass and yield components under different salinity and hormonal treatments

\begin{tabular}{lccc}
\hline Treatments & $\begin{array}{c}\text { Pods } \\
\text { per plant }\end{array}$ & $\begin{array}{c}\text { Seeds } \\
\text { per plant }\end{array}$ & $\begin{array}{c}\text { Maximum seed } \\
\text { mass } \\
\left(\mathrm{mg} \mathrm{seed}^{-1}\right)\end{array}$ \\
\hline Salinity & & & \\
$0 \mathrm{dS} \mathrm{m}^{-1}$ & $10.16 \mathrm{a}$ & $33.62 \mathrm{a}$ & $103.52 \mathrm{a}$ \\
$4 \mathrm{dS} \mathrm{m}^{-1}$ & $9.58 \mathrm{a}$ & $30.93 \mathrm{~b}$ & $103.31 \mathrm{ab}$ \\
$7 \mathrm{dS} \mathrm{m}^{-1}$ & $8.33 \mathrm{~b}$ & $27.33 \mathrm{c}$ & $96.73 \mathrm{~b}$ \\
$10 \mathrm{dS} \mathrm{m}^{-1}$ & $7.33 \mathrm{c}$ & $23.60 \mathrm{~d}$ & $89.32 \mathrm{c}$ \\
\hline Hormonal & & & \\
treatment & & & $96.80 \mathrm{~b}$ \\
Con & $8.25 \mathrm{~b}$ & $27.30 \mathrm{~b}$ & $104.37 \mathrm{a}$ \\
SA & $9.81 \mathrm{a}$ & $32.53 \mathrm{a}$ & $92.50 \mathrm{~b}$ \\
JA & $8.50 \mathrm{~b}$ & $26.76 \mathrm{~b}$ & $\mathrm{C}$ \\
\hline
\end{tabular}

Different letters in each column indicate significant difference at $\mathrm{p} \leq 0.05$. Con: control, SA: salicylic acid and JA: Jasmonic acid 


\section{DISCUSSION}

The decrement in CCI under severe salinity could be attributed to a salt-induced weakening of proteinpigment-lipid complex and enhancing the activity of chlorophyllase. The decrease in chlorophyll content under salt stress is commonly reported phenomenon (Noreen et al., 2009). Increasing the CCI and anthocyanins content with SA treatment may be related to increasing nitrogen absorption with the enhancing nitrate reductase activity (Farhangi-Abriz \& GhassemiGolezani, 2016) and increasing the chlorophyll stability index (Farhangi-Abriz \& Ghassemi-Golezani, 2018).

The low $\mathrm{Fv} / \mathrm{Fm}$ value under saline condition is the consequence of initial damage occurring in PSII, likely due to low water availability. This reduction in $\mathrm{Fv} / \mathrm{Fm}$ under salt stress is dependent on damage to reaction centers and reducing electron transport capacity in PSII (Ghassemi-Golezani \& Lotfi, 2015). Increasing PSII efficiency with SA treatment under severe salinity could be resulted from the effects of SA on decreasing the harmful effects of salt stress on plant performance (Farhangi-Abriz \& Ghassemi-Golezani, 2018). Exogenous application of salicylic acid on mustard plants improved photosynthetic activities and growth through increasing ascorbate-glutathione metabolism and sulphur assimilation under salt stress (Nazar et al. 2015). Increasing $\mathrm{Fv} / \mathrm{Fm}$ may be related to the effects of SA on inhibition of peroxidation of membrane lipid, decreasing electrolyte leakage and enhancement of electron transfer in membrane (Shi et al., 2006; Farhangi-Abriz \& Ghassemi-Golezani, 2018).

Increasing leaf temperature under salinity is related to low relative water content. One of the early symptoms of salinity stress in plant tissue is the decrease of RWC. This reduction of RWC in stressed plants may be associated with a decrease in plant vigor and was observed in many plant species. The decrease in leaf water could be associated with ion toxicities, ion imbalance and osmotic stress (Farhangi-Abriz \& Ghassemi-Golezani, 2018). Reduction in RWC leads to enhanced temperature via closing stomata and decreasing transpiration. Reducing the leaf temperature by SA application closely related with higher RWC of plants treated with this hormone. This may be resulted from the accumulation of so-called SA induced proteins that were found in all plant species and can have a helpful effect on the osmoregulation process in plants (Farhangi-Abriz \& Ghassemi-Golezani, 2018).

Reduction of leaf area and leaf dry mass under salinity could be attributed to the nutritional imbalance due to an interference of salt ions, such as $\mathrm{Na}^{+}$and $\mathrm{Cl}^{-}$with $\mathrm{K}^{+}$ involved in both uptake and translocation processes (Farhangi-Abriz \& Ghassemi-Golezani, 2018).
Potassium is a main plant macro-element that has some serious roles related to cell expansion and nutrient uptake. Restraining leaf expansion and reducing specific leaf area by salinity resulted in increasing specific leaf mass. Improving leaf area of soybean plants by SA application may be related to enhance essential nutrient uptake (Farhangi-Abriz \& Ghassemi-Golezani, 2018) and inhibition of ethylene synthesis (Leslie \& Romani, 1986). This leads to an increase in specific leaf area and a decrease in specific leaf mass. In contrast, JA application increases ethylene synthesis, which limits leaf area expansion, but increases leaf dry matter and specific leaf mass, probably with allocation of photo assimilate to produce secondary metabolites such as flavonoids and storing these metabolites in leaf cell vacuoles (Wasternack, 2007).

Increasing relative electrolytic leakage of leaves under salinity shows the extent of membrane damages due to salt toxicity. The lipid peroxidation and increasing relative electrolytic leakage under salinity are the serious adverse effects of the salinity on plant cells. Treatment with SA and JA decrease adverse effects of salinity by increasing anti-oxidants activity (FarhangiAbriz \& Ghassemi-Golezani, 2018), inhibiting ethylene synthesis (Leslie \& Romani, 1986), increasing RWC, $\mathrm{CCI}$ and allocation of amino acids to producing nonstructural protein in vegetative sinks (Farhangi-Abriz \& Ghassemi-Golezani, 2016).

Decreasing WUE under salinity stress is largely related to limitation of crop growth. These reductions in growth of soybean under salinity might be caused by decreasing turgidity from high concentrations of $\mathrm{Na}^{+}$in the soil under salt stress. The negative effect of salinity on plants may provoke osmotic potential by salt in the culture medium, so root cells do not obtain required water from the soil. Consequently, the uptake of some mineral nutrients such as nitrogen dissolved in water is also restricted (Farhangi-Abriz \& Ghassemi-Golezani, 2016). Increasing WUE by SA treatments could be the result of improving water uptake, translocation and increasing physiological performance and photosynthetic activities (Farhangi-Abriz \& GhassemiGolezani, 2018). Treatment with JA in some plants, reduces water and nutrient uptake, imbalances nutrient content and WUE, and reduces plant growth and seed production (Creelman \& Mullet, 1995; GhassemiGolezani \& Farhangi-Abriz, 2018b).

Reduction in seed filling duration and increment in seed filling rate of plants with increasing salinity stress is the result of early plant senesces (Farhangi-Abriz \& Torabian, 2017) and increasing ethylene synthesis (Cao et al., 2007). Yang et al. (2013) reported that a reformed 
hormonal balance in rice seeds during seed filling, especially a decrease in gibberellic acids and an increase in abscisic acid, enhances the remobilization of prestored assimilated to the seeds and accelerates the seed filling rate. The decreasing maximum seed mass of soybean seeds under salinity is related to limitation of water and nutrient uptake (Cao et al., 2007) and decreasing seed filling duration. Treatment with SA by preventing ethylene synthesis in plants and regulating hormonal balance (Leslie \& Romani, 1986) increased seed filing duration and maximum mass of seeds. In contrast, JA treatment by enhancing ethylene synthesis (Creelman \& Mullet, 1995) and seed filling rate, reduced seed filling duration (only on 0 and $4 \mathrm{dS} \mathrm{m}^{-1}$ ). Consequently, the maximum mass of seeds did not significantly change by JA, compared with untreated plants.

Reduction of assimilates mobilization efficiency under moderate and high salinity levels could be attributed to decreasing water availability, seed filling duration and photosynthetic activities. Foliar spray of SA increased assimilates mobilization to the seeds by rising seed filling period and improving water use efficiency. Decreasing assimilates mobilization efficiency by JA under non and low salinity conditions most likely related to the reduction of the seed filing period and allocation of assimilates to the vegetative sinks (Farhangi-Abriz \& Ghassemi-Golezani, 2016).

Pod number per plant is closely related with nod and flower number. Salinity could reduce nods and flowers per plant, leading to reduction in pods per plant. Treatment with SA increased number of pods and seeds per plant through improving flower-inducing factor (Hayat et al., 2007). Farhangi-Abriz and GhassemiGolezani (2018) reported that salinity can severely limit crop production, because high salinity reduces water potential and induces ionic stress. Large reductions in seed filling period, assimilate mobilization efficiency to the seeds, number of seeds and seed mass under saline conditions resulted in a considerable decrease in seed mass per plant. Exogenous application of SA improved seed mass via increasing morpho-physiological performance of plants, seed filling period, assimilate mobilization efficiency to the seeds, seed number per plant and seed mass. Foliar spray of SA decreases damages of salinity by increasing the activities of antioxidant enzymes, and also improving the general physiological performance of plants (Farhangi-Abriz \& Ghassemi-Golezani, 2018), which result in higher seed mass.

\section{CONCLUSIONS}

Salt stress considerably reduced seed mass of soybean by decreasing morpho-physiological performance of plants and seed filling duration. Foliar application of SA improved seed production under different levels of salt stress. The advantages of SA treated plants in seed mass were directly related with improving physiological performance of soybean plants such as leaf growth, water use efficiency, seed filling duration and assimilate mobilization efficiency under non-saline and saline conditions.

\section{REFERENCES}

Aftab, T., Khan, M. M. A., Idrees, M., Naeem, M., Hashmi, N. (2011). Methyl jasmonate counteracts boron toxicity by preventing oxidative stress and regulating antioxidant enzyme activities and artemisinin biosynthesis in Artemisia aпnиа L. Protoplasma, 248, 601-612. doi:10.1007/s00709010-0218-5

Barrs, H.D., Weatherley, P.E. (1962). A re-examination of the relative turgidity technique for estimating water deficits in leaves. Australian Journal of Biological Sciences, 15, 413-428. doi:10.1071/BI9620413

Cao, W.H., Liu, J., He, X.J., Mu, R.L., Zhou, H.L., Chen, S.Y., Zhang, J.S. (2007). Modulation of ethylene responses affects plant salt-stress responses. Plant physiology, 143, 707-719. DOI: doi:10.1104/pp.106.094292
Choudhury, S., Panda, S.K. (2004). Role of salicylic acid in regulating cadmium induced oxidative stress in Oryza sativa L. roots. Bulgarian Journal of Plant Physiology, 30, 95-110.

Creelman, R.A., Mullet, J.E. (1995). Jasmonic acid distribution and action in plants: regulation during development and response to biotic and abiotic stress. Proceedings of the National Academy of Sciences, $\quad 92, \quad 4114-4119$. doi:10.1073/pnas.92.10.4114

Farhangi-Abriz, S., Ghassemi-Golezani, K. (2016). Improving amino acid composition of soybean under salt stress by salicylic acid and jasmonic acid. Journal of Applied Botany and Food Quality, 89, 243-248. 
Farhangi-Abriz, S., Ghassemi-Golezani, K. (2018). How can salicylic acid and jasmonic acid mitigate salt toxicity in soybean plants? Ecotoxicology and Environmental Safety, 147, 1010-1016. doi:10.1016/j.ecoenv.2017.09.070

Farhangi-Abriz, S., Torabian, S. (2017). Antioxidant enzyme and osmotic adjustment changes in bean seedlings as affected by biochar under salt stress. Ecotoxicology and environmental safety, 137, 6470. doi:10.1016/j.ecoenv.2016.11.029

Ghassemi-Golezani, K., Farhangi-Abriz, S. (2018a). Foliar sprays of salicylic acid and jasmonic acid stimulate $\mathrm{H}^{+}$-ATPase activity of tonoplast, nutrient uptake and salt tolerance of soybean. Ecotoxicology and environmental safety, 166, 18-25. doi:10.1016/j.ecoenv.2018.09.059

Ghassemi-Golezani, K., Farhangi-Abriz, S. (2018b). Changes in Oil Accumulation and Fatty Acid Composition of Soybean Seeds under Salt Stress in Response to Salicylic Acid and Jasmonic Acid. Russian Journal of Plant Physiology, 65, 229-236. doi:10.1134/S1021443718020115

Ghassemi-Golezani, K., Lotfi, R. (2015). The impact of salicylic acid and silicon on chlorophyll a fluorescence in mung bean under salt stress. Russian journal of plant physiology, 62, 611-616. doi:10.1134/S1021443715040081

Ghassemi-Golezani, K., Taifeh-Noori, M., Oustan, S., Moghaddam, M., Seyyed-Rahmani, S. (2010). Oil and protein accumulation in soybean grains under salinity stress. Notulae Scientia Biologicae, 2, 6469. doi:10.15835/nsb224590

Gunes, A., Inal, A., Alpaslan, M., Eraslan, F., Bagci, E. G., Cicek, N. (2007). Salicylic acid induced changes on some physiological parameters symptomatic for oxidative stress and mineral nutrition in maize (Zea mays L.) grown under salinity. Journal of Plant Physiology, 164, 728-736. doi:10.1016/j.jplph.2005.12.009

Hayat, S., Ali, B., Ahmad, A. (2007). Salicylic acid: biosynthesis, metabolism and physiological role in plants. In Salicylic acid: A plant hormone. Springer, Dordrecht. doi:10.1007/1-4020-5184-0

Jiang, H., Egli, D.B. (1993). Shade induced changes in flower and pod number and flower and fruit abscission in soybean. Agronomy Journal, 85, 221225.

doi:10.2134/agronj1993.00021962008500020011x

Leslie, C. A., Romani, R. J. (1986). Salicylic acid: a new inhibitor of ethylene biosynthesis. Plant Cell Reports, 5, 144-146. doi:10.1007/BF00269255
Luo, Q., Yu, B., Liu, Y. (2005). Differential sensitivity to chloride and sodium ions in seedlings of Glycine max and G. soja under $\mathrm{NaCl}$ stress. Journal of plant physiology, 162, 1003-1012. doi:10.1016/j.jplph.2004.11.008

Lutts, S., Kinet, J. M., Bouharmont, J. (1996). NaClinduced senescence in leaves of rice (Oryza sativa L.) cultivars differing in salinity resistance. Annals of botany, 78, 389-398. doi:10.1006/anbo.1996.0134

Maclachlan, S., Zalik, S. (1963). Plastid structure, chlorophyll concentration, and free amino acid composition of a chlorophyll mutant of barley. Canadian Journal of Botany, 41, 1053-1062. doi:10.1139/b63-088

Mancinelli, A.L. (1984). Photoregulation of anthocyanin synthesis: VIII. Effect of light pretreatments. Plant Physiology, 75, 447-453. doi:10.1104/pp.75.2.447

Mirfattahi, Z., Karimi, S., Roozban, M.R. (2017). Salinity induced changes in water relations, oxidative damage and morpho-physiological adaptations of pistachio genotypes in soilless culture. Acta agriculturae Slovenica, 109, 291-302. doi:10.14720/aas.2017.109.2.12

Mohammadian, R., Moghaddam, M., Rahimian, H. Sadeghian, S.Y. (2005). Effect of early season drought stress on growth characteristics of sugar beet genotypes. Turkish journal of agriculture and forestry, 29, 357-368.

Nazar, R., Umar, S., Khan, N.A. (2015). Exogenous salicylic acid improves photosynthesis and growth through increase in ascorbate-glutathione metabolism and $\mathrm{S}$ assimilation in mustard under salt stress. Plant signaling \& behavior, 10 . doi:10.1080/15592324.2014.1003751

Noreen, S., Ashraf, M., Hussain, M., Jamil, A. (2009). Exogenous application of salicylic acid enhances antioxidative capacity in salt stressed sunflower (Helianthus annuus L.) plants. Pakistan Journal of Botany, 41, 473-479.

Oya, T., Nepomuceno, A. L., Neumaier, N., Farias, J. R. B., Tobita, S., Ito, O. (2004). Drought tolerance characteristics of Brazilian soybean cultivars. Plant Production Science, 7, 129-137. doi:10.1626/pps.7.129

Reddy, M.P., Vora, A.B. (1986). Salinity induced changes in pigment composition and chlorophyllase activity of wheat. Indian Journal of plant physiology, 29, 331-334.

Sali, A.L.I.U., Rusinovci, I., Fetahu, S., Gashi, B., Simeonovska, E., Rozman, L. (2015). The effect of 
Salicylic acid and jasmonic acid alter physiological performance, ... seed filling of soybean under salt stress

salt stress on the germination of maize (Zea mays L.) seeds and photosynthetic pigments. Acta agriculturae Slovenica, 105, 85-94. doi:10.14720/aas.2015.105.1.09

Shi, Q., Bao, Z., Zhu, Z., Ying, Q., Qian, Q. (2006). Effects of different treatments of salicylic acid on heat tolerance, chlorophyll fluorescence, and antioxidant enzyme activity in seedlings of Cucumis sativa L. Plant growth regulation, 48, 127-135. doi:10.1007/s10725-005-5482-6
Wasternack, C. (2007). Jasmonates: an update on biosynthesis, signal transduction and action in plant stress response, growth and development. Annals of botany, 100, 681-697. doi:10.1093/aob/mcm079

Yang, D.L., Yang, Y., He, Z. (2013). Roles of plant hormones and their interplay in rice immunity. Molecular plant,

6 , 675-685. 